\title{
Relationship between Energy Intake and Obesity Prevalence among Adolescent Girls in Aceh Barat
}

\author{
${ }^{1}$ Afwa Hayuningtyas, ${ }^{2}$ Wardah Iskandar, ${ }^{3}$ Suci Eka Putri, ${ }^{4}$ Safrida, ${ }^{5}$ Adelina Irmayani Lubis \\ ${ }^{1}$ Teuku Umar University, Indonesia, afwahayuningtyas@utu.ac.id \\ ${ }^{2}$ Teuku Umar University, Indonesia, wardahiskandar@utu.ac.id \\ ${ }^{3}$ Teuku Umar University, Indonesia, suciekaputri@utu.ac.id \\ ${ }^{4}$ Teuku Umar University, Indonesia, safridam.si@utu.ac.id \\ ${ }^{5}$ Teuku Umar University, Indonesia, adelina.irmayani@utu.ac.id \\ Corresponding Author : Afwa Hayuningtyas, afwahayuningtyas@utu.ac.id
}

\begin{abstract}
The prevalence of adolescent obesity has been shown to differ among regions, and it could be influenced by several factors, including diet, environmental exposures, and lifestyle. Diet is one of the crucial factors that contribute to obesity among adolescents, particularly energy intake. This study was conducted to measure the relationship between energy intake and obesity prevalence among adolescent girls in Aceh Barat Regency. This study is descriptive-analytical research with the design of a cross-sectional study. The population in this study were adolescent girls in Aceh Barat Regency with samples of 50 people. The data were obtained from a one-day 24-hour recall and analyzed using the Chi-Square test with a significance value $(\mathrm{p}=0.05)$. The result showed that based on bivariate analysis, there is a relationship between energy intake and body mass index. The study indicated that adolescent girls with excessive energy intake had a 6.67-fold higher risk of obesity than those with adequate energy intake (OR: 6.67, 95\% CI: 1.25 35.65).
\end{abstract}

ARTICLE INFORMATION

\author{
Submitted: $30 / 10 / 2021$ \\ Revised: $31 / 10 / 2021$ \\ Accepted: $31 / 10 / 2021$ \\ Publish Online: 06/11/2021
}

Keywords:

Adolescent

Body Mass Index

Energy Intake

Obesity

How to cite this article: Hayuningtyas, A., Iskandar, W., Putri, S.E., Safrida, Lubis, A.I., (2021). Relationship between Energy Intake and Obesity Prevalence among Adolescent Girls in Aceh Barat. Journal of Nutrition Science, 2 (2), $12-14$

\section{Introduction}

Chronic diseases, particularly obesity, have been an emerging health problem in Indonesia for over a decade. Various factors have been discovered to contribute to this emerging trend: nutrition intake, environmental exposures, and lifestyle (Pelletier \& Gage, 1995).

Adolescence is a period where there is a change in eating and activity behavior in girls. At this time, adolescents are no longer dependent on parental giving and food choices. Coupled with decreased participation in physical activity and sports, it can cause energy balance to impact weight gain. Currently, adolescents often consume foods based on popular trends without paying attention to the nutritional content (Todd, et al., 2015).

Adolescents' nutrition issues arise because of those inappropriate dietary habits, causing an imbalance between nutritional intakes and the recommended dietary allowances. If this condition is done continuously, it will cause weight gain (Wirjatmadi, \& Adriani, 2012). Weight gain can lead to obesity in adolescents, defined as excessive accumulation of fat in the body (Barasi, 2007). Obesity is caused by an imbalance between energy intake and energy expenditure (Gibney et al., 2009).

In Indonesia, the prevalence of obesity has increased. In 2003, 2007, and 2018 the problem of obesity in Indonesia was $10.5 \%, 14.8 \%$, and $21.8 \%$. This prevalence tends to increase from year to year. The data from Riskesdas 2018 shows that the prevalence of overweight and obesity is $16.0 \%$ in adolescents aged 13-15 years and $13.5 \%$ in adolescents aged 1618 years (Kemenkes, 2018).

Individuals with severe obesity encounter severe and potentially life-threatening complications, including 
diabetes, hypertension, hyperlipidemia, asthma, and arthritis (Mokdad et al., 2003). A study by Suchindran, et al., (2010) reported that obese adolescents were significantly more likely to develop severe obesity in young adulthood than normalweight adolescents (hazard ratio: 16.0, 95\%, CI: 12.4-20.5). Obesity increases the risks of mortality and morbidity and hampers the physical and psychological functions that impact the quality of life (Khodijah, et al., 2013).

A study by Nugroho (2020) reported that women have a risk of 0.595 -fold higher than men. At the same time, the adolescents ( $<14$ years old) had a risk of 1,490-fold higher than the young adulthood (> 14 years old). Various factors could be the cause of obesity among adolescents. One of the crucial factors is diet, particularly energy intake. This study aims to determine the relationship between energy intake and obesity prevalence among adolescent girls in Aceh Barat.

\section{Method}

This study is descriptive-analytical research with the design of a cross-sectional study. The population in this study were adolescent girls in Aceh Barat Regency, with the number of sample of 50 people. The cross-sectional design was used because the measurement of dependent and independent variables of the study was carried out simultaneously. The dependent variable in this study is body mass index, and the independent variable is energy intake. The data were obtained from a one-day 24-hour recall.

The data obtained were then analyzed using SPSS software. The statistical test methods used in this study include univariate analysis by looking for the frequency distribution and bivariate analysis using the Chi-Square test with a significance value $(p=0.05)$ to see the relationship between energy intake and body mass index.

\section{Results}

Table 1. The Frequencies Distribution Category of Energy Intake and Body Mass Index

\begin{tabular}{lcc}
\hline Variable & $\begin{array}{c}\text { Frequency } \\
(\mathbf{n})\end{array}$ & $\begin{array}{c}\text { Percentage } \\
(\%)\end{array}$ \\
\hline Energy Intake & & \\
$\quad$ Adequate & 40 & 80 \\
Excessive & 10 & 20 \\
Body Mass Index & & \\
$\quad$ Normal & 27 & 54 \\
Obesity & 23 & 46 \\
\hline
\end{tabular}

Table 1. shows that among the population, the percentage of those who have adequate energy intake is $80 \%$, while those who have excess energy intake are $20 \%$. Furthermore, $54 \%$ of the population is categorized as normal in the body mass index, while the remaining $46 \%$ are classified as obese.

Table 2. Chi-Square Test Result of Relationship between Energy Intake and Body Mass Index

\begin{tabular}{lcccccccc}
\hline \multirow{2}{*}{$\begin{array}{l}\text { Intake } \\
\text { Intaky }\end{array}$} & \multicolumn{4}{c}{ Body Mass Index } & \multirow{2}{*}{ Total } & P- & \multirow{2}{*}{ OR } \\
\cline { 2 - 6 } & \multicolumn{2}{c}{ Normal } & \multicolumn{2}{c}{ Obesity } & & & Value & \\
\hline Adequate & 25 & 50 & 15 & 30 & 35 & 80 & 0.03 & 6.67 \\
Excess & 2 & 4 & 8 & 16 & 10 & 20 & & \\
\hline *OR $=6.67$ & $(125$ & $-35.65)$ & & & & &
\end{tabular}

Bivariate analysis results showed that the p-value obtained is $0.03(\mathrm{P}<0.05)$, meaning a relationship between energy intake and body mass index. Based on Table 2. excessive energy intake is highly associated with the higher obesity prevalence (16\% out of 20\%). Moreover, the analysis indicated that adolescent girls with excessive energy intake had a 6.67-fold higher risk of obesity than those with adequate energy intake (OR: 6.67, 95\% CI: 1.25 $35.65)$.

\section{Discussion}

The results of the univariate analysis showed that about $20.6 \%$ of adolescent girls have excess energy intake, and $46 \%$ were categorized as obese. Excessive energy intake can trigger obesity in individuals if the energy expenditure is less than energy intake.

Nowadays, in Aceh Barat, various foods are widely available in the market, both energy-dense foods and drinks. These foods are considered one of the factors that cause energy intake to be higher than individuals' biological and physiological needs. Besides that, low physical activity levels are also possible contributors to obesity (Ocké et al. 2009).

The bivariate analysis results prove excessive energy intake with the possibility of obesity (Table 2.). Namely, there is a relationship between excess energy intake in adolescent girls with a high prevalence of obesity, $16 \%$ from $20 \%$ with a risk reaching 6.67-fold higher than in adolescent girls with adequate energy intake (OR: 6.67, 95\% CI: 1.25-35.65).

This study was in line with a study by Harahap et al. (2018), which reported that children (6-12 years of age) with excessive energy intake (>100\% RDA) had 
a higher risk of obesity (OR: 4.2, 95\% CI: 1.9-9.3) of being obese than children with adequate energy intakes $(=100 \%$ RDA). Another report by Pampang et al. (2009) studied the relationship between energy intake and obesity prevalence of junior high school students in Yogyakarta, reporting a significant difference between students who had an adequate energy intake and excessive energy intake on obesity prevalence. Students with excessive energy intake had a 6.9-fold higher risk of obesity than those with sufficient energy intake ( $\mathrm{p}<0.001$; OR: 6.9, 95\% CI: 3.84-12.59).

Based on this description, it can be concluded that there is an emerging health problem in adolescents regarding the risk of obesity so that efforts to prevent obesity in adolescents are needed by the government and the private sector in the form of community empowerment, health, promotion, and public policy.

\section{Conclusion}

This study concluded that there is a relationship between energy intake and obesity prevalence among adolescent girls. The analysis showed that adolescent girls with excessive energy intake had a 6.67-fold higher risk of obesity than those with adequate energy intake (OR: 6.67, 95\% CI: 1.25-35.65). The result indicated that it is necessary to design tactical efforts in community empowerment, health promotion, and public policy to prevent obesity in adolescents by the government and the private sector.

\section{References}

Barasi, M.E. (2007). Ilmu Gizi. Jakarta At a Glance: Erlangga.

Gibney, M. J., Margetts, B. M., \& Kearney, J. M. (2009). Arab 1. Gizi kesehatan masyarakat. Jakarta: EGC, 100-5.

Harahap, H., Sandjaja, S., Soekatri, M., Khouw, I., \& Deurenberg, P. (2018). Association of energy intake and physical activity with overweight among Indonesian children 6-12 years of age.
Asia Pacific journal of clinical nutrition, 27(1), 211-216.

Kemenkes RI. 2018. Laporan hasil riset kesehatan dasar (riskesdas) Indonesia tahun 2018. Jakarta: Kementerian Kesehatan Republik Indonesia;

Khodijah, D., Lukman, E., \& Munigar, M. (2013). Obesitas dengan kualitas hidup remaja. Jurnal Health Quality, 3(2), 69-140.

Nugroho, P. S. (2020). Jenis Kelamin dan Umur Beresiko terhadap Obesitas pada Remaja di Indonesia. An-Nadaa: Jurnal Kesehatan Masyarakat, 7(2), 110-114.

Pampang, E., Purba, M. B., \& Huriyati, E. (2009). Asupan energi, aktivitas fisik, persepsi orang tua, dan obesitas siswa dan siswi SMP di Kota Yogyakarta. Jurnal Gizi Klinik Indonesia, 5(3), 108-113.

Pelletier, D. L., \& Gage, T. (1995). Recent trends in obesity and chronic disease in developing countries. Washington, DC: International Food Policy Research Institute.

Suchindran, C., North, K. E., Popkin, B. M., \& Gordon-Larsen, P. (2010). Association of adolescent obesity with risk of severe obesity in adulthood. Jama, 304(18), 2042-2047.

Todd, A.S, dkk. (2015). Overweight and Obese Adolescent Girls: The Importenace of Promoting Sensible Eating and Activity Behaviors from the Start of the Adolescent Period. International Journal of Environmental Research and Public Health, 12, 2306-2329; doi:10.3390/ijerph120202306.

Ocke, MC., Larrañaga, N., Grioni, S., van den Berg, S.W., Ferrari, P. et al. (2009). Energy intake and sources of energy intake in the European Prospective Investigation into Cancer and Nutrition. European Journal of Clinical Nutrition, $63 \quad$ : $\quad$ S3-S15. doi:10.1038/ejen.2009.72.

Wirjatmadi, B., \& Adriani, M. (2012). Pengantar gizi masyarakat. Jakarta Kencana Prenada Media Gr. 